\title{
Servant Leadership: Responding the Challenges for Change in Higher Education
}

\author{
Annisa Lutfia*, Udin Saefudin Sa'ud, Deden Saepudin \\ Educational Administration Department, School of Postgraduate Studies \\ Universitas Pendidikan Indonesia \\ Bandung, Indonesia \\ *annisa.annisalutfia@gmail.com
}

\begin{abstract}
This study aims to describe servant leadership characteristics possessed by leaders of higher education institutions. This is important because higher education institutions as the center of excellence are required to answer the challenges for change demanded by the market, and servant leadership is the most suitable leadership characteristics to do so. The present study employed qualitative method. The primary data was collected through in-depth interview with the head of tarbiyah faculty of Sunan Gunung Djati State Islamic University, Bandung, as well as via observation and documentation. In addition, questionnaires were administered to 11 heads of programs at tarbiyah faculty of the university to collect secondary data. The findings of this study show that servant leadership should possess the characteristics of organizational stewardship, wisdom, service, humility, vision, persuasive mapping, altruistic, and emotional healing.
\end{abstract}

Keywords-challenges, change, higher education, responding, servant leadership

\section{INTRODUCTION}

Globalization requires structural changes in both profitbased and non-profit organizations to anticipate the effects it brings about. An organization and all functions existing in it must have competitive edge and competitive competence. Every organization is required to improve its quality, its innovation, and its services to compete in the global market, and this also applies to education institution. The changes in quality demand and technological advances in various fields have required universities to continuously improve to create academic products that benefits the society. Consequently, competition in educational industry becomes harder and the demands for competitive advantages increase. Globalization has created a foundation for a new paradoxical civilization which can be positive or negative, depending on how ready an individual or an organization to handle it $[1,2]$.

Industrial revolution is a real phase happening in the limitless world of industry. The effect of 4.0 Industrial Revolution is widespread and affecting all aspects of human life. It will also determine global economic development in the future $[3,4]$. The challenges that university graduates face in
4.0 Industrial Revolution era are increasing, which is why every university graduate need to have excellent competences to compete globally.

In higher education management, the demand for change can only be satisfied if the leadership and management are well developed [5]. Universities must prepare excellent and competent human resources so that they can survive the everchanging situation. The tight competition requires everyone to struggle to survive in such an environment. The way universities handle or utilize such condition reflects their ability to compete. Servant leadership views leadership from a different perspective. Servant leaders brings out the full potentials of their subordinates [6].

Leaders who possess servant leadership quality build it internally, because true leadership is born in one's self before moving outwards to serve those whom they lead. Characteristics and integrity of a leader becomes very important so that the subordinates can accept the leader. In higher education management, challenges for change can be handled effectively when leadership and management are well developed. Experts have compared servant leadership with other types of leadership and stated that servant leadership shares a lot of similarities with transformational leadership. The similarities are in terms of certain characteristics, such as vision, influence, credibility, trust, and service. However, servant leadership is deemed better than transformational leadership because it involves an alignment of motives between the leader and the subordinates [7,8]. The servant leadership model was developed based on eight characteristics, i.e. altruistic calling, emotional healing, wisdom, persuasive mapping, organizational stewardship, humility, vision, and service [9].

Several previous studies have shown that servant leadership is a strong predictor for preparing educational institutions for change. Servant leadership is considered successful in a competitive environment because it can increase trust, respect for others, increase the empowerment, and productivity of its members. Servant leadership does not focus on the role or position themselves in the organization, instead, they focus on the final goal and foster their community to be part of the 
change process [10-12]. Servant leadership style has a high positive value in providing job satisfaction at the faculty. Job satisfaction will affect staff performance directly and ultimately will improve organizational performance. For the success of the faculty in showing high performance, it requires high job satisfaction between educators and staff.

Based on the phenomenon and main points, researchers are interested in explaining the dimensions of servant leadership and categorizing them based on their hierarchy importance of servant leadership dimension.

\section{RESEARCH METHODOLOGY}

The present study employed descriptive-analytic method using qualitative approach. The writers chose to implement this approach and method with consideration to the need for indepth examination and analytical review of characteristics that servant leaders should possess in facing the challenges for change in universities. Descriptive method helped the researchers to gather observational data to support the primary data [13].

Participants in this study were grouped into primary and supporting participants. Primary participants consisted of the Dean, the First Vice Dean of Academics, the Second Vice Dean of General, Planning, and Financial Administration, and the Third Vice Dean of Students, Alumni, and Relationship Affairs. Meanwhile, supporting participants were comprised of eleven heads of departments in the faculty of tarbiyah. The 11 departments were Islamic Education Management, Islamic Education, Arabic Education, English Education, Mathematic Education, Biology Education, Chemistry Education, Physics Education, Madrasah Ibtidaiyah Teacher Education, Early Childhood Islamic Education, and Teacher's Professional Education.

Data was gathered through interviews, observations, and documentation. Primary participants were interviewed in-depth to collect data on servant leadership characteristics implemented by the leaders of tarbiyah faculty to respond to the demands for change by preparing competent human resources, making innovations, and being open to ongoing changes. Data from supporting participants were collected through questionnaires. The questionnaires used Likert scale and contained a modified version of Barbuto and Wheeler's servant leadership scale which consisted of 5 dimensions: altruistic calling, emotional healing, wisdom, persuasive mapping, and organizational stewardship. These five dimensions did not fully cover or represent Wong and Page's conceptual framework for measuring servant leadership [14] Hence, this study added three more dimensions to Barbuto and Wheeler's five dimensions, i.e. service, humility, and vision. Therefore, wisdom and humility represent the characteristics of orientation; altruistic and emotional healing represent human characteristics; organizational stewardship, persuasive mapping, and vision represent task orientation; service represents a process category.
Participants were asked to judge the importance of servant leadership behavior so that the organization had greater opportunities to achieve its goals in particular situation. The sample of university leaders consisted of the head of faculty and the heads of programs (departments). Situations that reflected the needs for constant change faced by the dean were: 1) implementing Rector's policies and regulations; 2) managing internal management to maintain sustainable academic activities; 3 ) managing the interests of various parties existing in the faculty; 4) satisfying the demand to continuously improve the quality of learning and research; 5) increasing the faculty's capacity to support the university in competing in national and international levels. The participants were asked to judge the importance of the head of faculty's actions and behaviors in those situations using five scales: NI (Not Important), QI (Quite Important), I (Important), VI (Very Important), and VVI (Very Very Important or Necessity).

\section{FINDINGS AND DISCUSSION}

\section{A. Findings}

In general, the eight dimensions of servant leadership were considered important to have, especially for the head of tarbiyah faculty of Sunan Gunung Djati State Islamic University, Bandung. These dimensions were crucial for the institution that has been continuously changing. To make research results display simpler, they were categorized in certain themes based on the similarities of participants' responses for each value. The resulting data is as table 1 follow:

TABLE I. THE VALUE COMPONENT OF SERVENT LEADERSHIP

\begin{tabular}{|l|l|}
\hline Value & \multicolumn{1}{|c|}{ Participants } \\
\hline Service & $\begin{array}{l}\text { Leaders are required to be a model in terms of } \\
\text { behaviors, actions, and personal values and to } \\
\text { understand that service is the essence of leadership and } \\
\text { that serving other people is the most important thing. }\end{array}$ \\
\hline Humility & $\begin{array}{l}\text { Leaders are required to show humility, to not draw } \\
\text { attention to their own achievements, to not overestimate } \\
\text { their contribution, and to not think highly of themselves. }\end{array}$ \\
\hline Wision & $\begin{array}{l}\text { Looking for commitment from every member of the } \\
\text { organization towards the shared vision by inviting and } \\
\text { encouraging everyone to participate in formulate and } \\
\text { developing a vision }\end{array}$ \\
\hline Being aware of surrounding environments and being \\
able to anticipate consequences of one's actions were \\
deemed more important than merely knowing about and \\
being directly involved in everything that happened on \\
campus.
\end{tabular}


Table 1. Cont.

\begin{tabular}{|l|l|}
\hline Altruistic & $\begin{array}{l}\text { A leader should view leadership as a calling or a duty to } \\
\text { satisfy subordinates' needs. A leader should put } \\
\text { subordinates' interests above his own. Although leader } \\
\text { should be willing to sacrifice his own interest to fulfill } \\
\text { his subordinates' needs, he should not always do so. A } \\
\text { leader should balance the priority between his interest } \\
\text { and subordinates'needs. }\end{array}$ \\
\hline $\begin{array}{l}\text { Emotional } \\
\text { Healing }\end{array}$ & $\begin{array}{l}\text { A leader in higher education institution is not forced to } \\
\text { be talented in helping his subordinates to solve their } \\
\text { emotional problems, to help subordinates who is } \\
\text { experiencing emotional problems, and to lend a shoulder } \\
\text { for subordinates who is having emotional problems. }\end{array}$ \\
\hline
\end{tabular}

To determine the scale of servant leadership characteristics dimensions obtained from the results of a questionnaire that has been distributed. See figure 1 bellow.

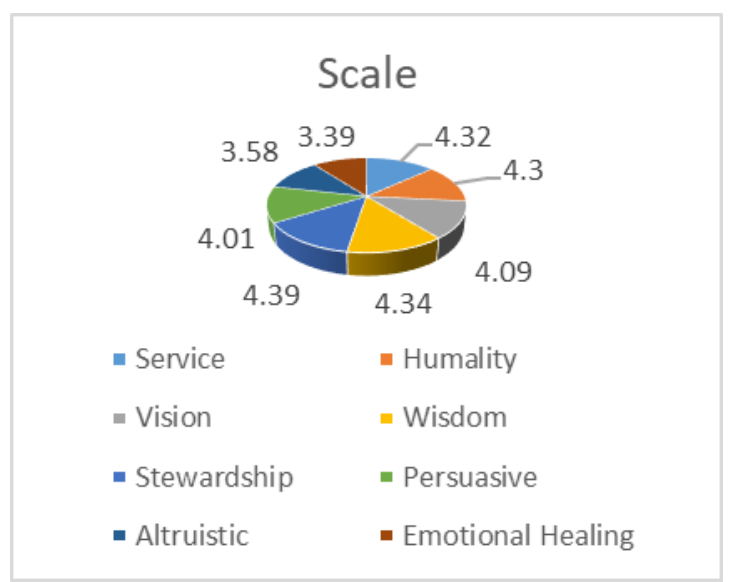

Fig. 1. The servant leadership value scale.

\section{B. Discussion}

The results of this study were, in some form, congruent with the findings of Barbuto and Wheeler [9]. They found that organizational stewardship and wisdom were the most important dimensions in leadership. They also found that organizational stewardship and wisdom were the best predictors of employees' willingness to do extra work and of employee satisfaction. In terms of emotional healing dimension, our finding was different from that of Barbuto and Wheeler [9]. Their finding indicated that employees viewed emotional healing as strongly related to employee satisfaction.

This study, however, found that emotional healing was least important compared to other dimensions of servant leadership. A leader of higher education institution in a situation of change was required to be able to prepare the faculty to develop positively in the future, to contribute positively to the society, and to internally grow the faculty as a community rather than a group of employees. In a situation of change, as was occurring in tarbiyah faculty of Sunan Gunung Djati State Islamic University Bandung, there was great expectation that the university would develop a better university in the future.

A leader was required to prepare and develop the institution to grow well towards the direction of expected changes. The next requirement in stewardship dimension was that internally, people working in the higher education institution could grow as a community. Wong and Davey argued that an important profile of a servant leader is the ability to view himself as a servant [15]. A characteristic of servant was cultivating stewardship, which meant that servant leader would believe that he was responsible and accountable for all his actions.

Consequently, as an elected steward, a leader was morally bound to perform his duties well. Being a leader meant fulfilling one's duties by helping the organization and the people within it as well as possible. Under a situation of change, it was important for a leader to know what was occurring in his university and his environment as well as to anticipate the consequences of his decisions. With the demand for change, a leader was required to give greater attention towards his surroundings. A leader would have to make a lot of decisions and every decision would bring its own consequences. Hence, it was logical that wisdom was the second most important value a leader should possess.

To satisfy the demand of wisdom, a leader should possess great intellect and knowledge. A leader should be competent, not only in his specialized field but also in humanity, to understand complex organizational issues, to handle opposing views and opinions, and to manage conflict wisely. In order to encourage and drive subordinates to form a community, a leader was required to be humble.

A leader should not be one-sided. A leader should be able to embrace people with opposing views because his priority was the common good. A leader should always be ready to understand and forgive other people. The dimension of service, which was not included in Barbuto and Wheeler's model, proved to be the third most important dimension in the present study. A leader was required to be a model for others, in this case a model of service. A leader should provide examples of servant leadership, of how to provide service to other people. The fact that service dimension was the third most important dimension justified the view that servant leadership was an important style of leadership to manage higher education institution.

Serving other people was the core of servant leadership. The primary motivation of this leadership style was helping other people and, if necessary, sacrificing one's interest to give the best for other people. A leader should pay great attention to building good relationship with other people. Having vision was considered the most important thing, in theory and in practice, for a leader. However, the results of this study showed that vision was ranked fifth, under stewardship, wisdom, service, and humility. Shared vision was the key of vision dimension. It meant that a leader might already have a vision to achieve, but he should remember that it was crucial to make his vision a shared vision [16].

\section{CONCLUSION}

The present study concluded that servant leadership could be an alternative for higher education leadership style in this 
age of constant change. Every dimension of servant leadership was important to implement. Organizational stewardship, wisdom, and services were the most important dimension of servant leadership in higher education institution. Meanwhile, emotional healing was the least important for leaders of higher education institution, even though the behaviors embedded in this dimension were deemed relatively important by most of the participants. This study also proved that the construct of servant leadership was unidimensional. In other words, it was a whole and comprehensive construct. The hierarchy of importance for servant leadership dimension to be implemented in higher education to answer the challenges for change were: organizational stewardship, wisdom, service, humility, vision, persuasive mapping, altruistic calling, and emotional healing

\section{ACKNOWLEDGMENT}

We would like to extend our gratitude to the head of tarbiyah faculty of Sunan Gunung Djati Islamic State University Bandung and the heads of departments in the faculty.

\section{REFERENCES}

[1] B. Edwards and A. Means, "Globalization, Privatization, Marginalization: Mapping and Assessing Connections and Consequences in/through Education," Educ. Policy Anal. Arch., vol. 27, no. 123, pp. 1-37, 2019.

[2] Z. Adiguzel, M. Faruk, and H. Karadal, "Does servant leadership moderate the link between strategic human resource management on rule breaking and job satisfaction?," Eur. Res. Manag. Bus. Econ., vol. 26, no. 2, pp. 103-110, 2020.
[3] M. Xu, J. M. David, and S. H. Kim, "The Fourth Industrial Revolution : Opportunities and Challenges," vol. 9, no. 2, pp. 90-95, 2018.

[4] M. Lee, J.J. Yun, A. Pyka, D. Won, F. Kodama, G. Schiuma, and X. Zhao, "How to respond to the fourth industrial revolution, or the second information technology revolution? Dynamic new combinations between technology, market, and society through open innovation," Journal of Open Innovation: Technology, Market, and Complexity, vol. 4, no. 3, p. 21, 2018.

[5] D. Jones, "The role of servant leadership in establishing a participative business culture focused on profitability, employee satisfaction, and empowerment.," Walden University, 2011.

[6] S. Goh and B. Zhen-jie, "The Influence of Servant Leadership towards Organizational Commitment: The Mediating Role of Trust in Leaders," vol. 9, no. 1, pp. 17-25, 2014.

[7] B.M. Bass and B.M. Bass, "The Future of Leadership in Learning Organizations," 2000.

[8] D. Van Dierendonck, "Servant Leadership : A Review and Synthesis," J. Manage., vol. 37, no. 4, pp. 1228-1261, 2011.

[9] J.E. Barbuto, D.W. Wheeler, and D.W. Wheeler, "Scale Development and Construct Clarification of Servant Leadership," Agric. Leadership, Educ. Commun. Dep., vol. 31, no. 3, pp. 300-326, 2006.

[10] L. Ten Brummelhuis, "The Relationship Between Servant Leadership, Quality Of Communication, Change Readiness, And Successful Change," University of Groningen, 2012.

[11] S.L. Iken, "UND Scholarly Commons Servant Leadership in Higher Education : Exploring Perceptions of Educators and Staff Employed in a University Setting," 2005.

[12] R. and M.M. Alonderiene, "Leadership style and job satisfaction in higher education institutions," Int. J. Educ. Manag., vol. 30, no. 1, pp. 140-164, 2016.

[13] L.J. Moleong, Metodologi penelitian kualitatif, Revisi. Bandung: PT Remaja Rosdakarya, 2018.

[14] P. Wong, "Servant leadership: An Opponent-Process Model and the Revised Servant Leadership Profile," no. 2000, pp. 1-13, 2003.

[15] D.M. Davey, "Best Practices in Servant Leadership," Servant Leadersh. Res. Roundtable, no. July, 2007.

[16] K. Patterson, “Servant Leadership :," no. August, 2003. 